\title{
Sexuality of Aruncus aethusifolius (Rosaceae)
}

\author{
Narae Yun, Hwa-Jung Suh and Sang-Hun Oh* \\ Department of Biology, Daejeon University, Daejeon 34520, Korea \\ (Received 21 August 2017; Revised 10 September 2017; Accepted 18 September 2017)
}

\begin{abstract}
Aruncus L. is a small genus which is distributed in the circumpolar regions of the Northern Hemisphere, including Europe, Asia, and North America. In Korea, there are two taxa, A. dioicus var. kamtschaticus and $A$. aethusifolius. Aruncus aethusifolius is a species endemic to Korea, occurring only on Jeju Island. An important characteristic of Aruncus is dioecy. However, there is some controversy regarding the sexuality of this genus, and little is known about $A$. aethusifolius. To characterize the sexuality of $A$. aethusifolius and to provide insight into the evolution of its sexual system, we investigated natural populations and herbarium specimens of $A$. aethusifolius. The results indicate that the species has carpellate, staminate, and bisexual flowers. Carpellate flowers are always borne on separate individuals, and staminate flowers are borne either on separate individuals or mixed with bisexual flowers on the same individuals. The sexuality of $A$. aethusifolius is defined as polygamo-dioecious. The polygamodioecious type is also found in $A$. dioicus var. dioicus and A. dioicus var. kamtschaticus and thus may be a general condition in Aruncus.
\end{abstract}

Keywords: Bisexual, dioecious, flower, Jeju Island, polygamo-dioecious

Aruncus L. is a small genus distributed in the circumpolar regions of the Northern Hemisphere, including Europe, Asia, and North America. Number of species in this genus varies depending on the author, with some recognizing one highly polymorphic species of $A$. dioicus (Walter) Fernald (Hara, 1955) or the three species of A. dioicus, A. gombalanus (Hand.-Mazz.) Hand.-Mazz., and A. aethusifolius (H. Lév.) Nakai (Gu and Alexander, 2003; Lee, 2007). Aruncus is easily distinguished from other genera in Rosaceae by several characters, such as dioecious, perennial herbs, 2-3-pinnately or 1-2-ternately compound leaves without stipules, paniculate inflorescences, and follicular fruits (Hutchinson, 1964; Henrickson, 1985; Kalkman, 2004). Recent phylogenetic analyses suggested that Aruncus is sister to Holodiscus (K. Koch) Maxim., which is a small erect, hermaphroditic shrub in western North America within the tribe Spiraeeae (Potter et al., 2007a, 2007b; Xiang et al., 2016). Plants of Aruncus are widely cultivated as ornamentals (Hutchinson, 1964) and young leaves, with high antioxidant activities (Shin et al., 2008), are often consumed as vegetables.

In Korea, there are two taxa. Aruncus dioicus var. kamtschaticus is distributed in the higher elevations of mountains on the Korean Peninsula and on Ulleung Island, but it has not been reported on Jeju Island. This taxon is widely distributed in East Asia from western China, Korea, to Japan with a wide range of morphological variation (Ikeda, 2001; Gu and Alexander, 2003; Lee, 2003; Lee, 2007). Aruncus aethusifolius is an endemic species of Korea, occurring only on Jeju Island. It is usually found in moist places near or crevices of volcanic rocks at elevations ranging from 1,500 to $1,800 \mathrm{~m}$ as part of the subalpine vegetation on Mt. Halla, and it occurs as well on moist banks along creeks of the mountain at elevations as low as $400 \mathrm{~m}$. Aruncus aethusifolius is occasionally thought of as a variety of A. dioicus (Hara, 1955; Lee, 2003), but it is considered to be a distinct species due to several unique morphological characteristics, such as a short plant stature, very short internodes in the stems, highly dissected leaflets, and erect follicles (Nakai, 1912; Lee, 1980; Lee, 2006; Lee, 2007).

One of key characters of Aruncus includes the sexuality of the species, in which staminate and carpellate flowers are developed in different individuals in a population, making it dioecious. Dioecious species is very rare among the approximately 90 genera and 3,000 species in Rosaceae,

\footnotetext{
*Author for correspondence: soh42@dju.kr
} 
occurring only in eight genera and approximately nine species (Table 1). Given that the vast majority of species in Rosaceae are hermaphroditic and considering the phylogeny of Rosaceae (Potter et al., 2007a; Xiang et al., 2016), dioecy in Rosaceae were likely derived independently in each of the species from hermaphroditic ancestors. Dioecy is also rare in angiosperms, found in about $6 \%$ of flowering plants (Renner and Ricklefs, 1995), in contrast to the animal system, in which gonochorism with separate males and females is found in $95 \%$ of all species (Jarne and Auld, 2006).

The rarity of dioecism in angiosperms has led to much attention regarding the evolution and development of separate genders (Darwin, 1877; Westergaard, 1958; Irish and Nelson, 1989; Renner and Ricklefs, 1995; Sakai and Weller, 1999; Charlesworth, 2015; Käfer et al., 2017; Pannell, 2017; Zuluvova et al., 2017). Several characteristics, such as woodiness, wind pollination, and large inflorescences with small white to green flowers, are associated with the evolution of dioecy. With regard to their geographic distribution, dioecious species are more common in the tropics and on oceanic islands, including Hawaii, in angiosperms (Renner and Ricklefs, 1995; Sakai and Weller, 1999; Käfer et al., 2017). Aruncus provides an intriguing system with which to study the evolution of dioecy, as it deviates from the general trends in the evolution of the sexual system. However, there is confusion regarding the sexuality of Aruncus among authors. While most authors (Radford et al., 1964; Ohwi, 1965; Gleason and Cronquist, 1991; Ikeda, 2001; Lee, 2007; Mellichamp and
Wetherwax, 2012; Mellichamp, 2014) have considered Aruncus to be dioecious, Gu and Alexander (2003) have found that Aruncus is monoecious, in which staminate and carpellate flowers are borne on the same plant. Tutin (1968) recognized that Aruncus is polygamo-dioecious, in which bisexual (or perfect) flowers are developed in some of the male or female plants in a population. Bond (1962) and Robertson (1974) showed that bisexual flowers are occasionally found in staminate inflorescences in $A$. dioicus var. dioicus in eastern North America, consistent with Tutin (1968). The occurrence of bisexual flowers is unknown in other varieties of $A$. dioicus and $A$. aethusifolius.

The objectives of this study are to characterize the sexuality of A. aethusifolius based on field observations and investigations of herbarium specimens and to provide insights into the evolution of sexual system of this species.

\section{Materials and Methods}

Field observations of $A$. aethusifolius were made on Mt. Hallasan on Jeju Island. Fifty-three herbarium specimens of $A$. aethusifolius and 190 specimens of $A$. dioicus var. kamtschaticus were examined in KB (the acronyms follow Thiers, 2017), TI, TUT, and Warm-Temperate and Subtropical Forest Research Center. A list of specimens of Aruncus aethusifolius examined in this study was provided in Appendix 1.

The sexuality of $A$. aethusifolius in a flower and a plant was determined under a microscope. A Nikon SMZ18 dissecting

Table 1. Genera or species with unisexual flowers in Rosaceae. Most genera with unisexual flowers are monotypic, except for Spiraea, Rubus, Fragaria, and Sanguisorba. In the cases of Spiraea, Fragaria, and Rubus, most species produce bisexual flowers. The tribal and supertribal classifications follow Potter et al. (2007b). Data were obtained from Hutchinson (1964), Tutin (1968), Gu et al. (2003), and Kalkman (2004).

\begin{tabular}{|c|c|c|c|}
\hline Sexuality & Genera (number of species) or species & High-level classification & Distribution \\
\hline \multirow[t]{8}{*}{ Dioecious } & Kageneckia Ruiz \& Rav. (1) & Pyreae & South America \\
\hline & Oemleria Rchb. (1) & Osmaronieae & western North America \\
\hline & Sibiraea Maxim. (1) & Spiraeeae & East Asia, Europe \\
\hline & Spiraea bella Sims & Spiraeeae & Bhutan, China, India, Nepal \\
\hline & Spiraea decumbens W. Koch & Spiraeeae & Europe \\
\hline & Rubus chamaemorus L. & Rosodae & $\begin{array}{l}\text { East Asia, Europe, North America } \\
\text { (circumpolar) }\end{array}$ \\
\hline & Fragaria virginiana Mill. & Potentilleae & North America \\
\hline & Cliffortia L. (1) & Sanguisorbeae & Africa \\
\hline \multirow[t]{4}{*}{ Monoecious } & Hagenia J. F. Gmel. (1) & Sanguisorbeae & Africa \\
\hline & Sanguisorba L. (15) & Sanguisorbeae & Africa, Eurasia, North America \\
\hline & Sarcopoterium Spach. (1) & Sanguisorbeae & Europe \\
\hline & Cliffortia (1) & Sanguisorbeae & Africa \\
\hline
\end{tabular}


stereomicroscope (Nikon, Tokyo, Japan) was used to examine and photograph the flowers. Each specimen was scored as a male or female plant. The proportion of bisexual flowers in a plant was approximated by the length of the inflorescence axis, with bisexual flowers divided by the total length of the inflorescence axis. Flowers of $A$. aethusifolius are very small and borne very tightly along the inflorescence axis. The proportion of bisexual flowers in each gender class was plotted.

\section{Results and Discussion}

Our examination of $A$. aethusifolius indicated that the species has complex patterns of sexuality (Fig. 1). Three types of flowers were found: carpellate (Fig. 1B), staminate (Fig. 1D), and bisexual (Fig. 1F) flowers. The flowers had four basic whorls: sepals, petals, stamens, and carpels. In the carpellate flowers, stamens were not fully developed such that the filaments were very short and the anthers minute (Fig. 1B). In the staminate flowers, rudimentary carpels were located at the center of the flower (Fig. 1D). The bisexual flowers had both stamens and carpels that were fully developed (Fig. 1F). Nectaries on the inner side of the hypanthium were developed in all three types of flowers, which attract pollinators (Fig. 1). The flowers of A. aethusifolius are borne in panicles of racemes with 2-9 lateral branches. Carpellate flowers are always borne in separate individuals, making them female (gynoecious) plants (Fig. 1A). There are male (androecious) plants bearing only staminate flowers (Fig. 1C). In some male plants, bisexual flowers were also developed with staminate flowers in an inflorescence (Fig. 1E). Bisexual flowers are located at the lower part of a branch or at the lateral branch of the inflorescence. These andro-polygamous plants have mixed of flowers, staminate and bisexual flowers. The proportion of bisexual flowers in andro-polygamous plants based on herbarium specimens varied, ranging from 22 to $79 \%$ (Fig. 2). Thus, the populations of $A$. aethusifolius consist of female, male, and andro-polygamous plants. Of the 53 specimens examined, 14 were female, 23 were male, and 16 were andropolygamous (Fig. 2). As a result, sexuality of $A$. aethusifolius is defined as polygamo-dioecious.

Polygamo-dioecious may be a general condition in Aruncus. An examination of 190 specimens of $A$. dioicus var. kamtschaticus collected in Korea, China, and Japan showed that one specimen from Mt. Hwangbyeongsan in Gangwon Province (Kwon 080727-080, KB278766) was andropolygamous. The presence of andro-polygamous plants in $A$. dioicus var. kamtschaticus, albeit rare, is consistent with our observations of $A$. aethusifolius. Thus, our investigations of the sexuality in A. aethusifolius and A. dioicus var. kamtschaticus support previous studies of $A$. dioicus var. dioicus (Bond, 1962; Tutin, 1968; Robertson, 1974).

The occurrence of andro-polygamous plants in a dioecious species is occasionally reported in Rosaceae. For example, flowers of Oemleria cerasiformis (Torr. \& A. Gray ex Hook. \& Arn.) J. W. Landon are usually unisexual, developed in separate plants. However, in rare cases, bisexual flowers are also found (Hess, 2014), though the frequency of bisexual flowers is largely unknown.

The frequency of andro-polygamous plants varies across species in Aruncus. The occurrence of an andro-polygamous plant is very rare in A. dioicus var. kamtschaticus, as described above. It is difficult to quantify the frequency of andropolygamous in the eastern North American A. dioicus var. dioicus. Robertson (1974) stated that it was 'occasionally' found. However, the frequency of andro-polygamous plants in A. aethusifolius is much higher than the frequency in A. dioicus. Of the 53 specimens examined, 16 (30\%) were andropolygamous (Fig. 2). The gender frequency based on herbarium specimens may be biased, as female and andro-polygamous plants could be over-represented. Female and andropolygamous plants bearing flowers or fruits could be prepared for specimens, while male plants may have been neglected when the flowers fell off. Our field study supports the underrepresentation of male plants in herbarium specimens. Among nearly 60 individuals of nine clumps of $A$. aethusifolius along the Youngsil trail of Mt. Hallasan, male plants were dominant. Plants of A. aethusifolius showed a patchy distribution pattern in the population. A clump consisted of two female plants (Fig. 1A), one clump contained three male and four andropolygamous plants (Fig. 1E), and the remaining clumps included male plants. Our field observation also shows that the frequency of andro-polygamous plants in A. aethusifolius is higher than that in A. dioicus.

Why does $A$. aethusifolius show a high frequency of andropolygamous plants? It may be that the fitness of bisexual flowers, the population size, the genetic mechanism of sex determination, or a combination of these factors is associated with the frequent development of bisexual flowers. The occurrence of the same pattern of sexuality in all taxa of Aruncus, including A. dioicus and A. aethusifolius, suggests that polygamo-dioecious is genetically determined. Given that its sister group, Holodiscus, and most other members of Spiraeeae are hermaphroditic (Table 1), the gender polymorphism and underlying genetic network in $A$. aethusifolius should have evolved in the most recent common ancestor of Aruncus. It is interesting to note that seeds produced 

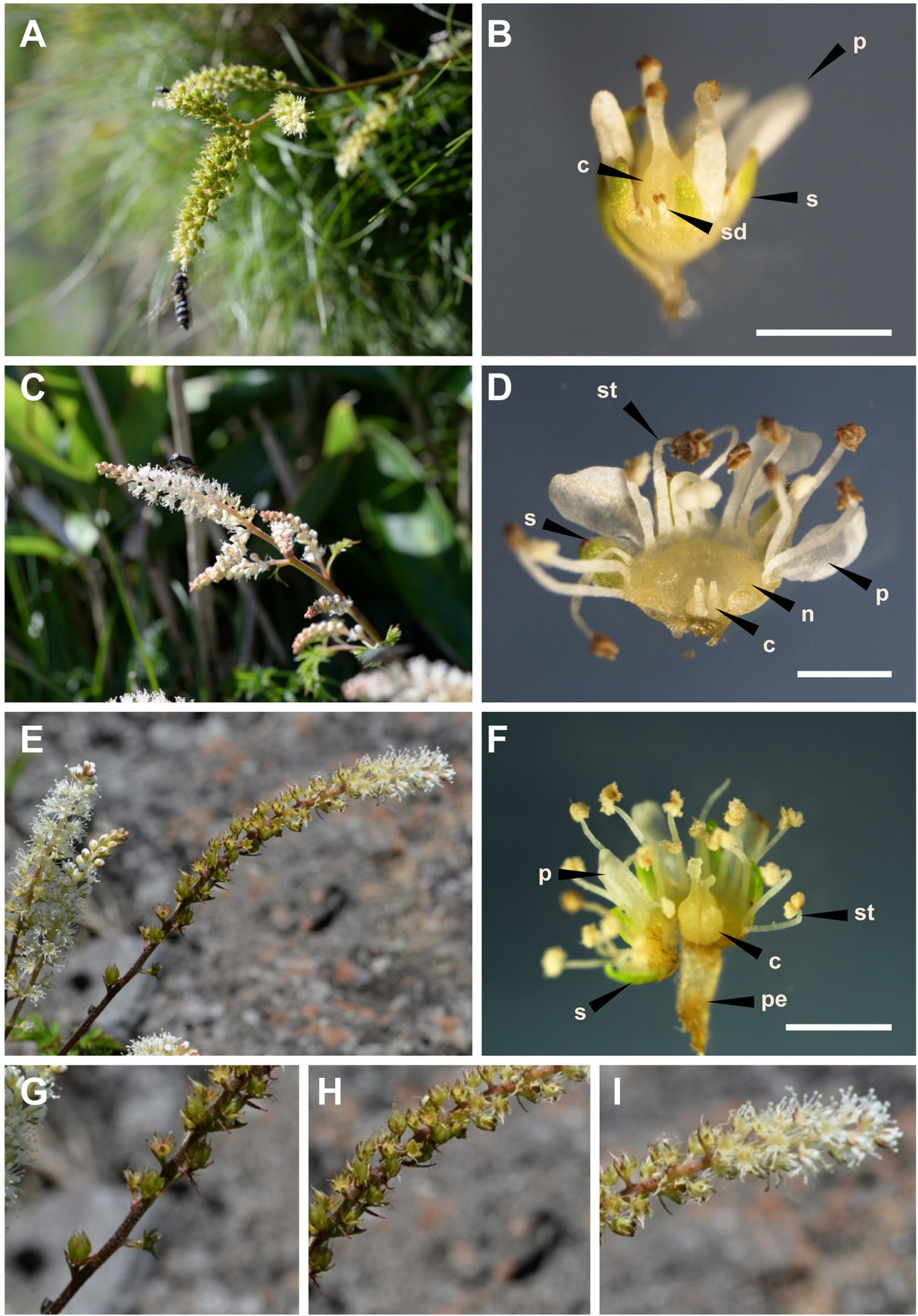

Fig. 1. Photographs of A. aethusifolius. A. Inflorescence of carpellate flowers. B. Carpellate flower. C. Inflorescence of staminate flowers. D. Staminate flowers. Parts of the hypanthium, stamens, and perianth were removed. E. Inflorescence mixed with bisexual and staminate flowers. F. Bisexual flowers. Parts of the hypanthium, stamens, and perianth were removed. G-I. Close-up of the inflorescence shown in E. c. carpel; $\mathrm{n}$, nectary; $\mathrm{p}$, petal; pe, pedicel; s, sepal; sd, staminode or rudimentary stamen; st, stamen. Scale bars $=1 \mathrm{~mm}$. 

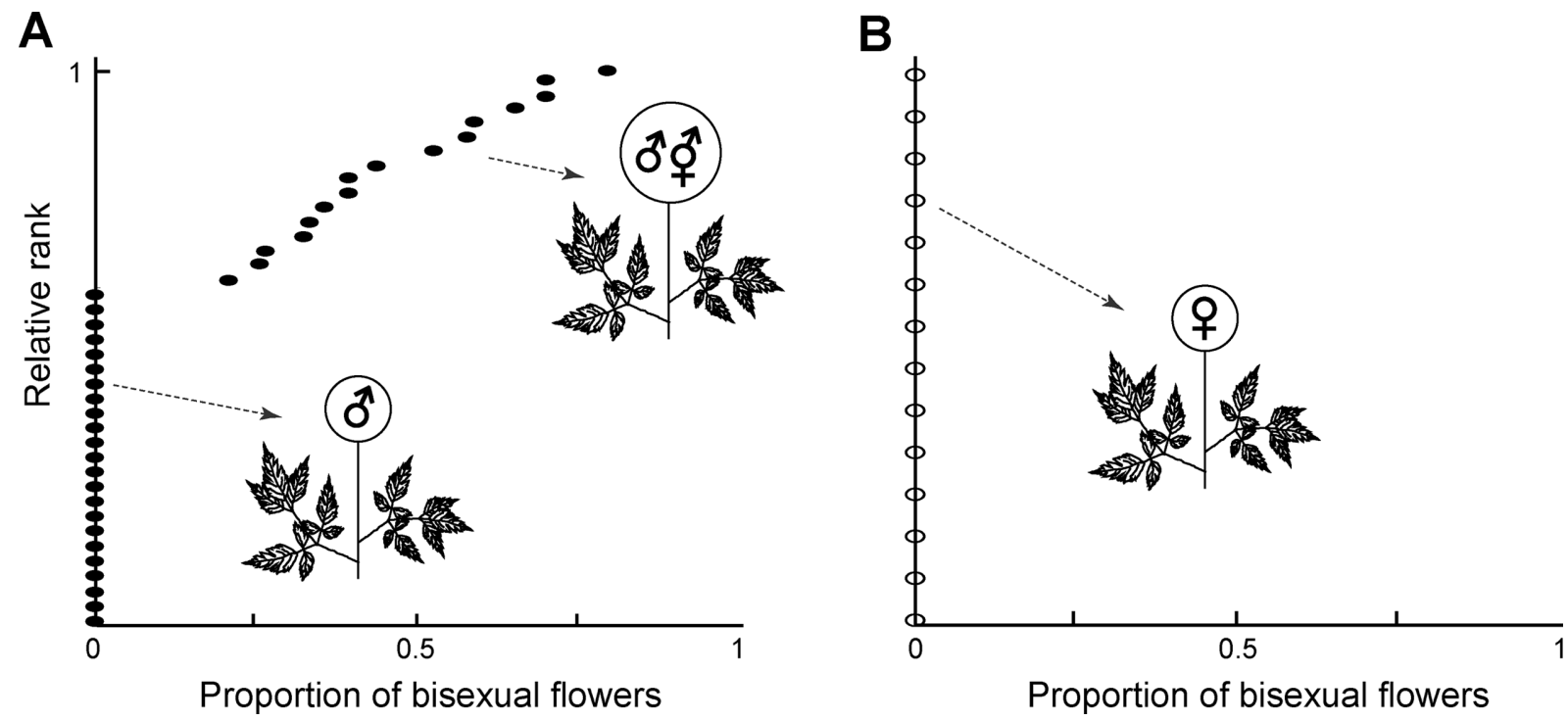

Fig. 2. Plot of the proportion of bisexual flowers. A. Male and andro-polygamous plants. B. female plants. Each circle represents one individual. For andro-polygamous plants, each plant was ranked according to the proportion of bisexual flowers and was plotted.

by bisexual flowers grow into andro-polygamous plants in $A$. dioicus var. dioicus (Bond, 1962). If we assume that this system applies to $A$. aethusifolius, the genotype of the andropolygamous plant is inherited and maintained in a population. The frequency of the genotype in A. aethusifolius may be high due to the large population size on Mt. Hallasan and indeed on Jeju Island. The large population size compared to A. dioicus may have played a role in the preservation of the genotype of the andro-polygamous plant.

The fitness of the andro-polygamous plants in $A$. aethusifolius may be greater than the fitness of andropolygamous plants in A. dioicus. Bisexual flowers are borne on the part of the male inflorescence, as described above (Fig. 2). Thus, the proportion of seeds from andro-polygamous plants in a population would decrease as the size of the inflorescence increases. The size of the panicles of female plants in $A$. dioicus is very large $(11-27.8 \mathrm{~cm}$ in length [mean $=17.5 \mathrm{~cm}])$, producing numerous follicles. In contrast, the size of the inflorescence of female plants in A. aethusifolius is small, ranging from 7.7 to $12.5 \mathrm{~cm}$ in length $($ mean $=9.4 \mathrm{~cm}$ ). This suggests that the magnitude of the difference in the number of seeds produced between carpellate and bisexual flowers in A. aethusifolius is smaller compared to that in $A$. dioicus. This would result in a higher proportion of seeds from bisexual flowers in a seed pool or bank in a population of $A$. aethusifolius. Further study of the gender specificity of these seeds is therefore necessary.

The genetic mechanisms which determine gender in plants are diverse (Pannell, 2017) because dioecy evolved multiple times from hermaphroditism. A genetic network for sex determination controlled by environmental signals was shown in Ceratopteris richardii Brongn. (Tanurdzic and Banks, 2004). Chromosomal sex determination has been widely studied in several angiosperms, such as Fragaria virginiana Mill. (Spigler et al, 2008), Sagittaria latifolia Willd. (Dorken and Barret, 2004), and Silene latifolia Poir. (Fujita et al., 2012). In monoecious plants such as melons and maize, the sexual identity of flowers as either male or female is determined by different genetic networks that react to hormones (Irish, 1999; Boualem et al., 2015). These case studies suggest that there is no general model of gender determination in plants. It would be interesting and important to study the sex determination mechanism in A. aethusifolius.

\section{Acknowledgments}

We are grateful to Drs. Hiroshi Ikeda, Byeong Yoon Lee, Won-Hee Kim, and Wha-Ja Hyun for allowing the specimen examinations necessary for this study, to Hyoujin Kim for the assistance with the imaging of the flowers under the microscope, and to Yoon Kyoung Choi for the help rendered when handling the herbarium specimens. We would like to thank two anonymous reviewers for their suggestions and comments. This research was supported in part by a grant from the National Institute of Biological Resources (NIBR), funded by the Ministry of Environment (MOE) of the Republic of Korea (NIBR201706101). 


\section{Literature Cited}

Bond, T. E. T. 1962. On bisexual flowers in Aruncus sylvester. Baileya 10: 89-91.

Boualem, A., C. Troadec, C. Camps, A. Lemhemdi, H. Morin, M. A. Sari, R. Fraenkel-Zagouri, I. Kovalski, C. Dogimont, R. Peri-Treves and A. Bendahmane. 2015. A cucurbit androecy gene reveals how unisexual flowers develop and dioecy emerges. Science 350: 688-691.

Charlesworth, D. 2015. Plant contributions to our understanding of sex chromosome evolution. New Phytologist 208: 52-65.

Darwin, C. 1877. The Different Forms of Flowers on Plants of the Same Species. Murray, London, 317 pp.

Dorken, M. E. and S. C. H. Barrett. 2004. Sex determination and the evolution of dioecy from monoecy in Sagittaria latifolia (Alismataceae). Proceedings of the Royal Society of London, B 271: 213-219.

Fujita, N., C. Torii, K. Ishii, W. Aonuma, Y. Shimizu, Y. Kazama, T. Abe and S. Kawano. 2012. Narrowing down the mapping of plant sex-determination regions using new Y-chromosomespecific markers and heavy-ion beam irradiation-induced Ydeletion mutants in Silene latifolia. G3: Genes Genomes Genetics 2: 271-278.

Gleason, H. A. and A. Cronquist. 1991. Manual of Vascular Plants of Northeastern United States and Adjacent Canada. 2nd ed. The New York Botanical Garden, Bronx, NY, 993 pp.

Gu, C. and C. Alexander. 2003. Aruncus. In Flora of China. Vol. 9 (Pittosporaceae through Connaraceae). Wu, Z. Y., P. H. Raven, and D. Y. Hong (eds.), Science Press, Beijing and Missouri Botanical Garden, St. Louis, MO. Pp. 74-75.

Gu, C., C. Li, L. Lu, S. Jiang, C. Alexander, B. Bartholomew, A. R Brach, D. E. Boufford, H. Ikeda, H. Ohba, K. R. Robertson and S. A. Spongberg. 2003. Rosaceae. In Flora of China. Vol. 9 (Pittosporaceae through Connaraceae). Wu, Z. Y., P. H. Raven, and D. Y. Hong (eds.), Science Press, Beijing and Missouri Botanical Garden, St. Louis, MO. Pp. 46-434.

Hara, H. 1955. Critical notes on some type specimens of East-Asiatic plants in foreign herbaria (2). Journal of Japanese Botany 30: $65-72$.

Henrickson, J. 1985. Xerospiraea, a generic segregate of Spiraea (Rosaceae) from Mexico. Aliso 11: 199-211.

Hess, W. J. 2014. Oemleria. In Flora of North America North of Mexico. Vol. 9. Flora of North America Editorial Committee (eds.), Oxford University Press, New York and Oxford. P. 385.

Hutchinson, J. 1964. The Genera of Flowering Plants. Dicotyledons, Vol. 1. Clarendon Press, Oxford, 510 pp.

Ikeda, H. 2001. Aruncus. In Flora of Japan. Vol. IIb: Angiospermae, Dicotyledoneae, Archichlamydeae (b). Iwatsuki, K., D.
E. Boufford, H. Ohba (eds.), Kodansha, Tokyo. Pp. 101-102. Irish, E. E. 1999. Maize sex determination. In Sex Determination in Plants. Ainsworth, C. C. (ed.), Bios Scientific, Oxford. Pp. 183-188.

Irish, E. E. and T. Nelson. 1989. Sex determination in monoecious and dioecious plants. Plant Cell 1: 737-744.

Jarne, P. and J. R. Auld. 2006. Animals mix it up too: The distribution of self fertilization among hermaphroditic animals. Evolution 60: 1816-1824.

Käfer, J., G. A. B. Marais and J. R. Pannell. 2017. On the rarity of dioecy in flowering plants. Molecular Ecology 26: 12251241.

Kalkman, C. 2004. Rosaceae. In The Families and Genera of Vascular Plants. Vol. 6. Flowering Plants-Dicotyledons: Celastrales, Oxalidales, Rosales, Cornales, Ericales. Kubitzki, K. (ed.), Springer, Berlin. Pp. 343-386.

Lee, S. 2007. Aruncus. In The Genera of Vascular Plants of Korea. Park, C.-W. (ed.), Academy Publishing Co., Seoul. Pp. 541542.

Lee, T. B. 1980. Illustrated Flora of Korea. 4th ed. Hyangmunsa, Seoul, 990 pp. (in Korean)

Lee, T. B. 2003. Coloured Flora of Korea. Hyangmunsa, Seoul, 910 pp. (in Korean)

Lee, Y. N. 2006. New Flora of Korea. Vol. 1. Kyohaksa, Seoul, 975 pp. (in Korean)

Mellichamp, T. L. 2014. Aruncus. In Flora of North America: North of Mexico. Vol. 9. Magnoliophyta: Picramniaceae to Rosaceae. Flora of North America Editorial Committee (eds.), Oxford University Press, New York and Oxford. Pp. 422-424.

Mellichamp, T. L. and M. Wetherwax. 2012. Aruncus. In The Jepson Manual: Vascular Plants of California. 2nd ed. Baldwin, B. G., D. H. Goldman, D. J. Keil, R. Patterson, T. J. Rosatti and D. H. Wilken (eds.), University of California Press, Berkeley. P. 1171.

Nakai, T. 1912. Notulae ad plantas Japoniae et Koreae. VIII. Botanical Magazine 26: 321-328.

Ohwi, J. 1965. Flora of Japan. Smithsonian Institution, Washington, D.C., $1067 \mathrm{pp}$

Pannell, J. R. 2017. Plant sex determination. Current Biology 27: R191-R197.

Potter, D., T. Eriksson, R. C. Evans, S. Oh, J. E. E. Smedmark, D. R. Morgan, M. Kerr, K. R. Robertson, M. Arsenault, T. A. Dickinson and C. S. Campbell. 2007a. Phylogeny and classification of Rosaceae. Plant Systematics and Evolution 266: 543.

Potter, D., S. M. Still, T. Grebenc, D. Ballian, G. Božič, J. Franjiæ and H. Kraigher. 2007b. Phylogenetic relationships in tribe Spiraeeae (Rosaceae) inferred from nucleotide sequence data. 
Plant Systematics and Evolution 266: 105-118.

Radford, A. E., H. E. Ahles and C. R. Bell. 1964. Manual of the Vascular Flora of the Carolinas. The University of North Carolina Press, Chapel Hill, 1183 pp.

Renner, S. S. and R. E. Ricklefs. 1995. Dioecy and its correlates in the flowering plants. American Journal of Botany 82: 596606.

Robertson, K. R. 1974. The genera of Rosaceae in the southeastern United States. Journal of the Arnold Arboretum 55: 303332.

Sakai, A. K. and S. G. Weller. 1999. Gender and sexual dimorphism in flowering plants: A review of terminology, biogeographic patterns, ecological correlates, and phylogenetic approaches. In Gender and Sexual Dimorphism in Flowering Plants. Geber, M. A., T. E. Dawson and L. F. Delph (eds.), Springer, Berlin. Pp. 1-31.

Shin, J.-W., S.-I. Lee, M.-H. Woo and S.-D. Kim. 2008. Effect of ethanol extracts of goat's beard on streptozotocin induced diabetic symptoms and oxidatives stress in rats. Journal of East Asian Society of Dietary Life 18: 939-948.

Spigler, R. B., K. S. Lewers, D. S. Main, T.-L. Ashman. 2008. Genetic mapping of sex determination in a wild strawberry, Fragaria virginiana, reveals earliest form of sex chromo- some. Heredity 101: 507-517.

Tanurdzic, M. and J. A. Banks. 2004. Sex-determining mechanisms in land plants. Plant Cell 16: S61-S71.

Thiers, B. 2017. Index Herbariorum: A global directory of public herbaria and associated staff. Retrieved Aug. 18, 2017, Available from: http://sweetgum.nybg.org/ih.

Tutin, T. G. 1968. Aruncus. In Flora Europaea. Vol. 2. Rosaceae to Umbelliferae. Tutin, T. G., V. H. Heywood, N. A. Burges, D. M. Moore, D. H. Valentine, S. M. Walters and D. A. Webb (eds.), Cambridge University Press, Cambridge. P. 6.

Westergaard, M. 1958. The mechanism of sex determination in dioecious flowering plants. Advances in Genetics 9: 217-281.

Xiang, Y., C.-H. Huang, Y. Hu, J. Wen, S. Li, T. Yi, H. Chen, J. Xiang and H. Ma. 2016. Evolution of Rosaceae fruit types based on nuclear phylogeny in the context of geological times and genome duplication. Molecular Biology and Evolution 34: 262-281.

Zuluvova, J., M. Nicolas, A. Berger, L. Negrutiu and F. Monéger. 2017. Premature arrest of the male flower meristem precedes sexual dimorphism in the dioecious plant Silene latifolia. Proceedings of National Academy of Sciences of the United States of America 103: 18854-18859.

\section{Appendix 1. A list of specimens of Aruncus aethusifolius examined in this study.}

KOREA. Jeju-do. Jeju-si: Yeon-dong, elev. 180 m, 18 Aug 2014, Cho M. S. et al. 140818008 (KB 519644); Yeongpyeongdong, elev. 450 m, 13 Aug 2008, Gyu Y. C. ANH_en_080813_005 (KB 197921); Mt. Hallasan, 24 Nov 2009, Kim C. S. et al. 28845 (WTFRC 100011016); Mt. Hallasan, 1 Nov 2011, Kim G. R. 33568 (WTFRC 10017850); Mt. Hallasan, 20 Aug 2009 , Kim J. 27610 (WTFRC 100011029); Mt. Hallasan, 24 Jul 2011, Kim J. 32119 (WTFRC 10016400 [2 plants]); Mt. Hallasan, 29 Jul 2011, Kim J. 32152 (WTFRC 10016433 [2 plants]); Mt. Hallasan, 23 Jul 1924, Saito s. n. (KB 543926, 544381, 547728); Mt. Hallasan, 27 Jul 2008, Song G. M. et al. 26142 (WTFRC 100011017); Mt. Hallasan, 20 Jul 2001, without collector and number (WTFRC 100011005). Seogwipo-si: Sanghyo-dong, elev. 570 m, 30 Aug 2011, Im H. T. 336112 0049 (KB 388519); Sanghyodong, Donnaeko Valley, elev. 550 m, 23 Oct 2011, Im H. T. Im61305 (KB 382410); Sanghyo-dong, elev. 506 m, 7 Aug 2010 , Kim C. H. et al. 50733 (KB 329762 [3 plants], 463109); Sanghyo-dong, 26 Jul 2005, Kim C. S. 3872 (KB 208594 [2 plants]); Namwon-eup, 15 Jul 2011, Kim G. R. 32072 (WTFRC 10016352 [2 plants]); Sanghyo-dong, 26 Jul 2005, Kim J. et al. 20764 (WTFRC 100011013); Yeongnam-dong, Mt. Hallasan, 7 Aug 2008, Kim J. et al. 26183 (WTFRC 100010985); Namwon-eup, 3 Aug 2006, Kim J. E. et al. 22785 (WTFRC 100011008-100011011); Namwon-eup, 3 Aug 2010, Kim J. E. 29971 (WTFRC 10014220 [4 plants]); Namwon-eup, elev. 597 m, 3 Aug 2010, Kim J. E. et al. 29971 (KB 318083); Mt. Hallasan, 19 Jun 2009 , Lee C. S. et al. leecs090987 (KB 256006); Namwon-eup, 21 Aug 2003, Moon M. O. et al. s. n. (WTFRC 100010986-100010991, 100010993, 100010994); Hawon-dong, Mt. Hallasan, 15 Jul 2014, Song J. H. \& OK M. K. sok201407 37 (KB 491953$)$; Sanghyodong, Donnaeko Valley, 2 Aug 2001, without collector and number (WTFRC 100010998, 100011000, 100011001, 100011003, 100011004); Namwon-eup, 28 Sep 2002, without collector and number (WTFRC 100010995). 